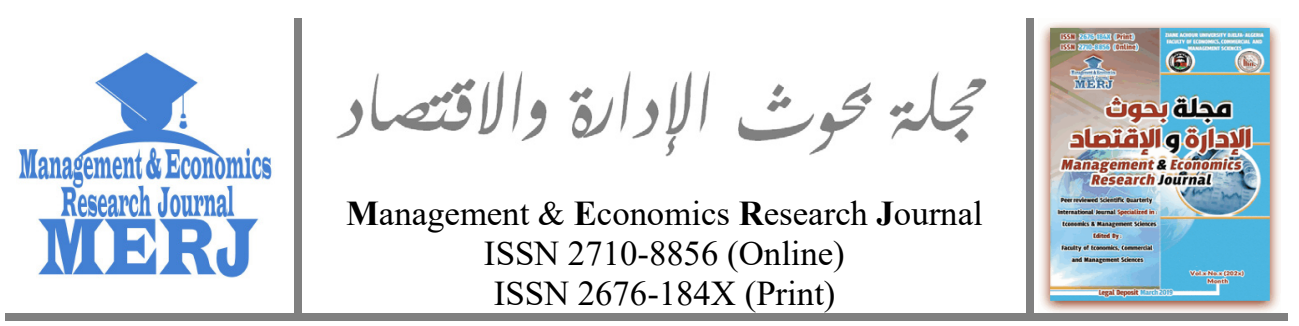

Vol. 4 No. 1 (2022): March, pp. 81-100

https://doi.org/10.48100/merj.2022.182

Check for updates

\title{
The Mediating Role of Organizational Commitment between Organizational Culture and Job Performance in the Telecommunication Sector
}

\author{
Alaa S. Jameel ${ }^{\star 1} \mathbb{D}$ \\ ${ }^{1}$ Department of Public Administration, Cihan University-Erbil, Kurdistan Region (Iraq) \\ $\bowtie$ alaa.salam@cihanuniversity.edu.iq
}

Received: 27-12-2021

Accepted: 03-02-2022

Published online: 05-02-2022

\begin{abstract}
How to Cite:
Jameel, A. S. (2022). The Mediating Role of Organizational Commitment between Organizational Culture and Job Performance in the Telecommunication Sector. Management \& Economics Research Journal, 4(1), 81-100. https://doi.org/10.48100/merj.2022.182
\end{abstract}

\begin{abstract}
:
This study investigates the impact of organizational culture on job performance and finds the mediating role of organizational commitment among telecommunication employees. The study analyzed 476 valid questionnaires from the employees of three telecommunication companies in Erbil, Iraq. However, the data was analyzed by Smart-PLS. The results indicated that the direct impact of organizational culture on job performance showed a positive and significant impact. Besides, the mediating role of organizational commitment can enhance and increase the impact of organizational culture on job performance among employees in the telecommunication sector. Furthermore, individuals in the workplace will exhibit different behaviors due to the deployment of culture-based strategies for behavior development. Therefore, job performance will increase if
\end{abstract}

- Corresponding author: Department of Public Administration, Cihan University-Erbil, Kurdistan Region (Iraq).

[\alaa.salam@cihanuniversity.edu.iq]

(C)2022 the Author(s). This is an open-access article distributed under the terms of (CC BY-NC 4.0) which permits use, distribution and reproduction in any medium, provided the original work is properly cited and is not used for commercial purposes.

Faculty of Economics, Commercial \& Management
Sciences, Ziane Achour University of Djelfa, BP
3117, Djelfa - Algeria


individuals and the workplace culture are in sync.

Keywords: Organizational Commitment, Organizational Culture, Job Performance, Telecommunication.

JEL Codes: M1, M2, M5.

\section{Introduction}

Due to its potential impact on organizational performance, organizational culture (OCU) has gotten much attention in the previous decades. This means that organizational culture may impact an organization's ability and performance to fulfill its goals and objectives; the individuals in the organization are also required to guarantee that its policies and strategies are implemented successfully. Organizational commitment (OC) is a psychological condition that describes an individual's relationship with their workplace. A dedicated individual stays with the company regardless of the company's positive or negative situations (Meyer \& Allen, 1997).

$\mathrm{OC}$ and organizational culture are essential antecedents of job performance (JP) (Carlos Pinho et al., 2014). Individuals more devoted and committed to their workplace are more likely to participate in the organization's activities and engage in good in-role and extra-role behaviors (Meyer \& Allen, 1991). However, Individuals committed and satisfied with their jobs are more likely to be motivated to work hard and exhibit positive work behaviors (Karem, Mahmood, et al., 2019).

Organizational culture changes will unavoidably impact organizations' and governments' overarching patterns and established structures. For example, organizational culture influenced behavior, morale, and production in the early 1980s, and new business leaders and thinkers recognized this. Nowadays, managers are more conscious of components of organizational culture such as traditions, laws and processes, rules, and requirements; hence, that will improve the employee's productivity and performance. Examining organizational culture and commitment is important because both impact organizational performance and can influence organizational outcomes (Carlos Pinho et al., 2014). For example, organizational culture is essential in establishing a set of core beliefs, understandings, and a healthy environment in the workplace where devoted people contribute positively to the organization's success (Ahmad et al., 2020).

Telecommunications companies are increasingly dedicated to implementing significant changes in response to expanding services, such as raising service quality requirements for consumers and implementing efficient and effective management procedures. In this setting, 
telecommunications companies' adoption of organizational culture is seen as a vital component, with organizational commitment possibly having a key role in enhancing organizational performance.

Limited studies were conducted among telecommunications companies. Most of the previous studies examined the impact of OCU on job performance in the context of consulting companies (Al-Musadieq et al., 2018), tourism (Alferaih, 2017), sports centers (Chiu et al., 2019), mediumsized companies (Maamari \& Saheb, 2018) and IT companies (Aranki et al., 2019). Furthermore, this study aims to enrich the body of knowledge in telecommunications and; to find the impact of organizational culture on job performance through the mediating role of organizational commitment.

\section{Literature review and hypotheses development}

\subsection{Job performance}

JP is an individual's conduct or activity (Jameel \& Ahmad, 2019b). Judge and Watanabe (1993) claim that honest self-evaluation significantly impacts JP. Staff with high self-assessment scores tend to be more motivated in the workplace. The team will perform better on the job as their confidence and talents grow, and self-evaluation is linked to staff satisfaction and performance. Individual capacity to carry out a specific task or obligation is a performance (Jameel et al., 2020).

According to Pujiono et al. (2020), JP is an indicator that compares job outcomes and responsibilities assigned to an employee over a particular time or period. JP can also reflect an organization's performance. According to Jameel and Ahmad (2020), an employee performs well when satisfying a specific set of requirements. Therefore, an organization with high-performing employees will gain acceptable outcomes, and employees will have a high degree of trust in the company. Employee job performance is the quality or quantity of job outcomes staff accomplish in carrying out their obligations (Gibson et al., 2011).

Individual work objectives or outcomes are directly connected to performance. Specific characteristics such as ability, effort, and task complexity can be linked to performance behavior (Pujiono et al., 2020). Performance results from actions taken to attain objectives and conform to standards. JP refers to the success of individuals in doing duties over time compared to work standards, objectives, or criteria set in advance and agreed upon (Sihombing et al., 2018). Jameel and Ahmad (2019b) indicated that performance alone is not enough but is linked to OCU, OC, satisfaction, and individual skills. Performance is linked to job satisfaction (Jameel \& Ahmad, 
2020) and rewards (Thabit \& Raewf, 2017).

Job performance, considered a building block of workplace and organization's development, is a collaborative effort of all its members (Isaac Mwita, 2000). Any organization's primary purpose is productivity enhancement, reduced staff turnover, and improved employee retention (Mowday et al., 1982).

Numerous studies support the importance of staff performance and have found a link between staff performance and various characteristics. Therefore, absorption and controlling performance within the context of objectives and benchmarks and undisputed-upon attribute criteria is a way to generate better outcomes from companies' individuals (Gani et al., 2018).

\subsection{Organizational culture}

There are many distinct definitions of culture in the previous works. However, academics generally agree that culture refers to familiar patterns of values and beliefs expressed in practices, behaviors, and other artifacts among the staff in the workplace (Hofstede, 1984; Trice \& Beyer, 1993). National culture is evaluated at the values level. In contrast, OCU fit is best determined at the practices level (Hofstede et al., 1990). According to Raharjo et al. (2018), the term 'cultural fit' is commonly used in the literature of Cartwright and Cooper."

OCU is essential for the success of a company and the satisfaction of knowledge-based products (Pujiono et al., 2020). To be competent, a leader must manage and understand the organizational culture to improve JP and sustain shareholder value. OCU has a significant impact on working conditions. Individual behavior, the environment, and how leadership is implemented inside an organization are all influenced by organizational culture based on values. OCU may be informal or unwritten, yet it significantly influences employees' thinking, attitudes, and viewpoints. According to Schein (1991), OCU is a group's shared fundamental assumptions while overcoming correct external and internal integration challenges. New team members may teach how to think, feel, and conduct themselves. Organizational culture is a common operating concept, including beliefs, values, rules, philosophies (Wallach, 1983), and ways of doing things (Maamari \& Saheb, 2018). However, it affects organizational decisionmaking, authority levels, and agency theory (Maamari \& Saheb, 2018). This element of the company has grown in importance and attention to assess its advancement and adaption to different cultures and how it affects performance (Maamari \& Saheb, 2018). According to Hofstede (2011), OCU is influenced by the country's national and societal culture. Society's culture 
has measurable aspects that can impact and shape the values and norms of the founders, staff, and customers of the companies positively or negatively (Hofstede, 2011). OCU is built on values, which are the most significant part. However, despite several measures to provide equal opportunity, this performance differs significantly by gender (Maamari \& Saheb, 2018). Since an organization's culture serves as a limit for both employees and managers, it controls and limits their behavior. As a result, an individual's or manager's performance is influenced by how well they are integrated and fit into the OCU (Maamari \& Saheb, 2018). Employees' ability to change their behavior to fit in with the workplace culture is becoming a key predictor of worker comfort and productivity inside organizations (Ahmad et al., 2021).

According to Ahmad et al. (2020), OCU consists of two dimensions: Attitude toward work, preferring work over other activities such as recreation, or just enjoyment from the work itself, or feeling compelled to do anything merely to keep one's life going and behaviors in the workplace such as effort, commitment, and commitment, care, assiduity, and meticulousness demonstrate a great readiness to acquire new jobs and responsibilities, such as assisting co-workers, or vice versa.

OCU could be a standard system of meaning individuals share that distinguishes the organization from others. Thus, the individuals build a shared meaning system, differentiating them from other organizations. On closer inspection, this system of shared meaning reveals a set of essential features that consider the organization's attitudes and values (Robbins \& Judge, 2003).

\subsection{Organizational commitment}

OC is the strength of an individual's identification with and involvement in a particular organization (Porter et al., 1974, p. 604). OC is a psychological condition that describes the individual relationship with the workplace and has ramifications for remaining or leaving the organization (Meyer \& Allen, 1991). OC is the degree to which an employee identifies with and participates in a particular organization (Al-Sada et al., 2017). Commitment refers to the circumstance in which an individual likes an organization and has the goal and desire to remain part of the organization (Robbins \& Judge, 2003). The psychological attachment to an organization is referred to as OC. In other words, OC has been defined as the psychological bond between employees and the company (Karem et al., 2019).

Commitment is a motivator that encourages individuals to do their best for what they are responsible for in the workplace. However, commitment in the workplace should not happen by accident; the 
organization and its individuals must work together to establish conditions that allow the intended commitment to be fulfilled. Organizational commitment is when individuals are physically linked to the workplace and can offer their best ideas, attention, and dedication to its success (Gani et al., 2018). The individual believes in the product or service of the company, promotes the company as an excellent place to work, is ready to sacrifice personal interests for the sake of the company's objectives, and remains with the company for several years despite being offered greater money elsewhere (Al-Sada et al., 2017).

According to Randeree and Ghaffar Chaudhry (2012), the core feature of commitment refers to individuals' desire to stay in their companies and not leave companies for self-benefit. Organizational commitment influences various issues, emphasizing the need to fully comprehend how this critical component operates (Jameel, Mahmood, et al., 2020).

Meyer and Allen (1991) specified that OC consists of three main dimensions: affective commitment, continuance commitment, and normative commitment. Affective commitment (AC) describes an individual's emotional attachment to the workplace; Continuance commitment (CC) describes an individual's assessment of the risks and costs of quitting their current job. The desire of individuals to stay in an organization is explained by their commitment to its aims, values, and standards, and they are an AC to the organization (Allen \& Meyer, 1996).

$\mathrm{CC}$ may be the staff sacrifice that may be entailed in quitting an organization and a lack of alternatives open to the staff (Massoudi et al., 2020). When staff continue to work for an organization, they feel a sense of obligation and responsibility to their employer for any reason, known as normative commitment (Karem, Mahmood, et al., 2019).

\subsection{Organizational culture and job performance}

Organizational culture influences how individuals function and engage in the workplace, and their self-perceptions, post-task appraisal, and performance (Beyer, 1990). Therefore, organizational performance is significantly connected to its culture. Therefore, when the organization has a strong, well-integrated culture built on strong principles and values, it will lead to high performance (Maamari \& Saheb, 2018). Organizational culture is essential for developing commitment and improving performance (Huey Yiing \& Zaman Bin Ahmad, 2009).

OCU enhances JP on a broad scale, and it helps employees learn about the organization's cultural history and present operating techniques (Maamari $\&$ Saheb, 2018). Individuals, groups, and organizations interact in a system 
where organizational culture influences individual performance, resulting in high performers being acknowledged and promoted more than low performance (Maamari \& Saheb, 2018). Additionally, the mutual benefit link between an organization and individuals supports this notion since all firms want to attract high-performance individuals to accomplish organizational goals and gain competitive advantages.

The internal integration of an organization's activities and personnel is organizational culture. Internal integration is defined by Maamari and Saheb (2018) as the socio-cultural interaction of new members with current members, which creates administrative boundaries and emotions of identity among employees and the commitment to the workplace. A strong organizational culture fosters adaptability and enhances individual performance by inspiring individuals toward common duties.

The world is changing, and culture must adapt (Hofstede, 2011). The most challenging issue for any company is to change its culture because workers are already used to it. In times of change, those accustomed to a specific way of doing things may find adapting difficult (Chatman et al., 1998). This takes us to the critical function of leadership and the need to rehabilitate organizational culture (Jameel \& Ahmad, 2019a).

Several previous studies indicated that organizational culture could increase and enhance job performance in the workplace. e.g. (Pujiono et al., 2020) reported that organizational culture improves job performance and has a positive and significant impact on the performance of the Ministry of Finance staff in Indonesia. Similarly (Al-Musadieq et al., 2018) indicated that JP is significantly impacted by organizational culture. In addition, several previous studies reported that organizational culture significantly affects JP in several contexts (Carlos Pinho et al., 2014; Gani et al., 2018; Maamari \& Saheb, 2018; Raharjo et al., 2018). Thus, the current study proposed the following hypothesis:

$\mathbf{H}_{1}$ : Organizational culture significantly predicts job performance.

\subsection{Organizational culture and organizational commitment}

Managers may utilize organizational culture as a crucial lever to guide the business (Ahmad et al., 2021). In addition, OCU may significantly impact organizational JP and commitment (Al-Sada et al., 2017). An OCU leads to more individual agreement, higher consistency in behavior, cohesion, OC, and lower turnover (Ahmad et al., 2020). In addition, organizations should foster a trusting culture in which individuals believe their organization is ready to take chances, experiment with fresh ideas, and put money into high- 
risk ventures (Karem et al., 2019).

In a business, the power of a company's culture to influence employee behavior and commitments is critical (Raharjo et al., 2018). Organizational culture is essential because it encompasses a wide range of beliefs, attitudes, well-received or not-so-well-received behaviors, methods of operation, and the corporate political climate, thus enhancing organizational commitment (Jameel et al., 2020; Jameel, Hamdi, et al., 2020). As a result, culture can increase organizational commitment and assure performance (Jameel \& Ahmad, 2019a).

Organizational culture is a powerful instrument for increasing an organization's commitment, and the greater the alignment of expressed and perceived values, the stronger the commitment (Aranki et al., 2019). An organization's success is determined by its ability to create a distinct corporate culture as part of its strategy. For example, reasonable compensation and awards are part of an influential culture that will increase employee commitment (Karem et al., 2019) and performance (Gani et al., 2018). OCU refers to the shared beliefs, ideas, traditions, and ways of working that influence how employees act and commit to the workplace (Ahmad et al., 2021).

Empirically, there are several pieces of evidence indicating that organizational culture enhances organizational commitment. Aranki et al. (2019) showed that organizational culture significantly impacts OC among the employees in IT companies in Jordan. Several studies reported that OCU significantly impacted OC (Gani et al., 2018; Raharjo et al., 2018; Sukasih \& Suardhika, 2019). On the other hand, (Carlos Pinho et al., 2014) reported that organizational culture has an insignificant impact on OC in health organizations. as discussed above, empirically, most of the results tend that OCU has a significant effect on OC.

$\mathbf{H}_{2}$ : Organizational culture significantly predicts organizational commitment.

\subsection{Organizational commitment and job performance}

Highly committed employees are more interested in offering more to the organization and putting out significant effort on behalf of the organization (Meyer et al., 1989; Mowday et al., 1982).

Chiu et al. (2019) indicated that committed individuals tend to make their best effort, which enhances job performance. Poor service offerings and more extraordinary expenses might negatively impact an organization's performance if personnel lack organizational commitment (Hamdi et al., 
2021). Conversely, employees with stronger loyalty to the company are more productive. (Chiu et al., 2019).

Low turnover and absenteeism of employees, high JP, and increased job effort are examples of how OC leads to positive behavioral outcomes among subordinates (Randall, 1990). individuals with high levels of OC outperform those with low levels of OC in JP (Karem, Mahmood, et al., 2019). Individuals who identify with the organization, have a sense of belonging, and are positively committed to the organization will perform better (Suharnomo \& Hashim, 2019). Employees who feel more support from the organization tend to show emotional commitment to the organization, which contributes to improved job performance (Xiu et al., 2019). Decreasing the likelihood of employee turnover and enhancing job performance are signs of an organizational commitment to its employees (Ahmad et al., 2021).

Based on several previous findings, OC can increase workplace job performance (Chiu et al., 2019; Chong \& Law, 2016; Hendri, 2019; Oyewobi et al., 2019; Raharjo et al., 2018). In another context, Suharnomo and Hashim (2019) reported that organizational commitment does not directly impact JP. While Carlos Pinho et al. (2014) also reported that OC had an insignificant impact on performance. However, based on the discussion above, most results reported that OC significantly impacts performance. performance.

$\mathbf{H}_{3}$ : Organizational commitment significantly predicts job

\subsection{The mediating role of organizational commitment}

OCU directly and positively impacts $\mathrm{OC}$ and job performance. However, little is known about OC as a mediator between OCU and JP. Several previous studies emphasized the importance of OC as a mediator between several factors.

Sihombing et al. (2018) indicated that OC mediated the impact of servant leadership on performance. Furthermore, Oyewobi et al. (2019) reported that OC partially mediates the impact of work-life balance on performance.

While limited studies examined the mediating role of $\mathrm{OC}$ between OCU and JP (Raharjo et al., 2018) examined the mediating role of job commitment between OCU and performance and reported that commitment mediated the impact of OCU on JP. Likewise, Gani et al. (2018) indicated the OC partially mediates the relationship between OCU and performance; thus, the following hypothesis is proposed: 
$\mathbf{H}_{4}$ : Organizational commitment would mediate the impact of organizational culture on job performance.

\section{Methodology}

This study considered descriptive as well as employed the deductive approach. The study used a questionnaire to collect data from the employees of three telecommunications companies in Erbil, Kurdistan Region of Iraq. The study also employed the simple random sampling strategy to reduce the likelihood of uneven participation. A representative sample is crucial in deriving conclusions from the outcomes of an investigation since it is an unbiased random selection. Six hundred questionnaires were distributed among the employees only 482 questionnaires were returned.

The questionnaire consisted of two main parts first was about the respondents' demographic information, and the second consisted of 20 items distributed among three variables. The questionnaire was also distributed in three languages: English, Arabic, and Kurdish, to be more accessible and understandable to employees. Moreover, the questionnaire was measured by five Likert scales. All 20 items were adopted from previous studies. JP was measured by seven items adopted from (Chapman et al., 2005) and (Pujiono et al., 2020). OC was measured by five items adopted from (Meyer \& Allen, 1997). Organizational Culture was measured by eight items adopted from (Denison \& Misra, 1995) and (Pujiono et al., 2020).

We used SPSS software to analyze the data. The valid questionnaires after conducting this step are 476 . The primary analysis was conducted by Smart-PLS 3.3.2 for measuring validity, reliability, and discriminate validity and examining the proposed hypotheses.

\section{Results}

According to (2017), two main steps should be conducted when the Smart-PLS measurement model and structural model analyze the data.

\subsection{Measurement model}

The purpose of this step is to evaluate the Factors loadings (FL), composite reliability (CR), Cronbach's alpha (CA), average variance extracted (AVE), and discriminant validity. The FL should be equal to or higher than 0.7 (Hair et al., 2017); all the items showed $<0.7$ and between 0.768 Orc 1 and 0.951 OC3, see Table 1 ; thus, all the items' loadings are at an acceptable level. Additionally, the reliability of constructs is assessed by CR 
and CA. The cut-off level for both indicators is equal to or higher than 0.7 (Hair et al., 2017). The three constructs showed high reliability and internal consistency in the results, as illustrated in Table 1 for CR between 0.934 JP and 0.947 Orc and the CA between 0.916 OC and Orc 0.936. finally, the AVE measures the variance value in each construct's indicators. The AVE should exceed 0.5 (Hair et al., 2017). All the constructs exceeded 0.5, as depicted in Table 1.

Table 1 . Validity and reliability

\begin{tabular}{|c|c|c|c|c|c|}
\hline Constructs & Items & FL & CR & CA & AVE \\
\hline \multirow{7}{*}{ Job performance } & JP1 & 0.849 & \multirow{7}{*}{0.934} & \multirow{7}{*}{0.917} & \multirow{7}{*}{0.669} \\
\hline & JP2 & 0.859 & & & \\
\hline & JP3 & 0.848 & & & \\
\hline & JP4 & 0.793 & & & \\
\hline & JP5 & 0.820 & & & \\
\hline & JP6 & 0.780 & & & \\
\hline & JP7 & 0.769 & & & \\
\hline \multirow{5}{*}{$\begin{array}{l}\text { Organizational } \\
\text { commitment }\end{array}$} & $\mathrm{OC} 1$ & 0.832 & \multirow{5}{*}{0.937} & \multirow{5}{*}{0.916} & \multirow{5}{*}{0.750} \\
\hline & $\mathrm{OC} 2$ & 0.861 & & & \\
\hline & $\mathrm{OC} 3$ & 0.915 & & & \\
\hline & OC4 & 0.914 & & & \\
\hline & OC5 & 0.802 & & & \\
\hline \multirow{8}{*}{ Organizational culture } & Orc1 & 0.768 & \multirow{8}{*}{0.947} & \multirow{8}{*}{0.936} & \multirow{8}{*}{0.691} \\
\hline & Orc2 & 0.796 & & & \\
\hline & Orc3 & 0.890 & & & \\
\hline & Orc4 & 0.879 & & & \\
\hline & Orc5 & 0.850 & & & \\
\hline & Orc6 & 0.846 & & & \\
\hline & Orc7 & 0.781 & & & \\
\hline & Orc8 & 0.830 & & & \\
\hline
\end{tabular}

\subsection{Discriminant validity}

The Discriminant Validity refers to the level of differentiating among all items for each construct compared to other items. However, the discriminant validity was measured by three methods.

First, by Fornell and Larcker's (1981) criterion, according to this method, each construct should be the square root of AVE correlated with itself higher than other constructs, as depicted in table 2. JP square root of AVE 0.818 higher than other constructs OC 0.598 and Orc 0.526 , and similar to other constructs see Table 2 . Thus, the first method has been achieved. 
Table 2. Fornell-Larcker criterion

\begin{tabular}{llll}
\hline & JP & OC & Orc \\
\hline JP & 0.818 & & \\
OC & 0.598 & 0.866 & \\
Orc & 0.526 & 0.457 & 0.831 \\
\hline
\end{tabular}

The second method to assess the discriminant validity is crossloading. According to Hair et al. (2017), a particular construct's loading items must load higher than others. As depicted in Table 3, the current result shows that all the loading items exceeded the cross-loadings. Thus, this method was achieved.

Table 3. Cross loadings

\begin{tabular}{llll}
\hline & JP & OC & Orc \\
\hline JP1 & 0.849 & 0.492 & 0.434 \\
JP2 & 0.859 & 0.507 & 0.448 \\
JP3 & 0.848 & 0.512 & 0.431 \\
JP4 & 0.793 & 0.574 & 0.449 \\
JP5 & 0.479 & 0.394 \\
JP6 & 0.820 & 0.438 & 0.423 \\
JP7 & 0.394 & 0.429 \\
OC1 & 0.769 & 0.832 & 0.437 \\
OC2 & 0.542 & 0.861 & 0.379 \\
OC3 & 0.568 & 0.915 & 0.402 \\
OC4 & 0.563 & 0.914 & 0.376 \\
OC5 & 0.513 & 0.802 & 0.384 \\
Orc1 & 0.454 & 0.768 \\
Orc2 & 0.371 & 0.426 & 0.796 \\
Orc3 & 0.417 & 0.431 & 0.890 \\
Orc4 & 0.438 & 0.426 & 0.879 \\
Orc5 & 0.503 & 0.327 & 0.850 \\
Orc6 & 0.429 & 0.338 & 0.846 \\
Orc7 & 0.396 & 0.257 & 0.781 \\
Orc8 & 0.508 & 0.336 & 0.830 \\
\hline
\end{tabular}

According to Kline (2016), the cut-off level of this method, the Heterotrait-Monotrait Ratio (HTMT), should be below 0.85. As depicted in Table 4, the current study results showed that all the values are less than 0.85 . thus, the third method has been achieved.

Table 4. Heterotrait-Monotrait ratio (HTMT)

\begin{tabular}{llll}
\hline & JP & OC & Orc \\
\hline JP & & & \\
OC & 0.640 & & \\
Orc & 0.564 & 0.486 & \\
\hline
\end{tabular}




\subsection{Structural model}

This stage aims to examine all the proposed hypotheses in Smart-PLS 3.3.2. This step is run by bootstrapping with 5000 subsamples, as recommended by (Hair et al., 2017).

The current step consisted of Four criteria. First, the R Square $\left(\mathrm{R}^{2}\right)$ and this criterion assess. The $\mathrm{R}^{2}$ refers to how much the exogenous explained the endogenous in the current study. As depicted in Table 5, the $\mathrm{R}^{2}$ from the direct effect of exogenous to endogenous is 0.43 . mean organizational culture explains 43 percent of the variance in JP and is considered substantial and acceptable based on Interpreting (Cohen, 1988). Additionally, the $\mathrm{R}^{2}$ between organizational culture and $\mathrm{OC}$ is 0.209 , meaning the variance is 20 percent, which is moderate and acceptable simultaneously (Cohen, 1988).

The second criteria are effect size $\left(\mathrm{F}^{2}\right)$. The current study results showed that the $\mathrm{F}^{2}$ from organizational culture to JP is 0.144 , from organizational culture to OC is 0.287 , and from OC to JP is 0.264 , as depicted in Table 5. These results could be small effect size and medium effect size, respectively (Cohen, 1988).

The third criteria are to measure the model's predictive accuracy $\left(\mathrm{Q}^{2}\right)$, which should be greater than zero; the $\mathrm{Q}^{2}$, as illustrated in Table 5, is 0.28 and 0.151 above 0 and acceptable (Hair et al., 2017).

Table 5. $\mathrm{F}^{2}, \mathrm{R}^{2}$, and $\mathrm{Q}^{2}$

\begin{tabular}{lllll}
\hline F Square & $\mathrm{JP}$ & $\mathrm{OC}$ & $\mathrm{R}^{2}$ & $\mathrm{Q}^{2}$ \\
\hline JP & & & 0.438 & 0.281 \\
OC & 0.287 & & 0.209 & 0.151 \\
Orc & 0.144 & 0.264 & & \\
\hline
\end{tabular}

In the final stage of the study, we will examine the four proposed hypotheses. The first hypothesis showed that OCU significantly impacted JP with a P-value of $0.00<0.05$ and T-statistics (T-value) 3.679 $>1.96$; thus, H1 was supported.

The second hypothesis indicated that organizational culture significantly enhances the $\mathrm{OC}$ with a P-value of $0.00<0.05$ and T- Statistics (T-value) $4.968>1.96$; thus, $\mathrm{H}_{2}$ was supported.

The third hypothesis showed OC significantly impacted JP with a Pvalue of $0.00<0.05$ and T-statistics (T-value) $5.037>1.96$; thus, $\mathrm{H}_{3}$ was supported.

The last hypothesis was proposed to examine the indirect effect of OCU on JP through the mediating role of OC. As depicted in Table 6, the indirect impact was positive and significant with a $\mathrm{P}$-value of $0.00<0.05$ and 
T-statistics (T-value) $3.627>1.96$; thus, $\mathrm{H}_{4}$ was supported.

Table 6. Hypotheses outcome

\begin{tabular}{llllll}
\hline Hypotheses & Original sample & $\begin{array}{l}\text { Sample } \\
\text { mean }\end{array}$ & $\begin{array}{l}\text { Standard } \\
\text { deviation }\end{array}$ & T-statistics & P-values \\
\hline $\mathrm{H}_{1}: \mathrm{OCU} \rightarrow \mathrm{JP}$ & 0.320 & 0.330 & 0.087 & 3.679 & 0.000 \\
$\mathrm{H}_{2}: \mathrm{OCU} \rightarrow \mathrm{OC}$ & 0.457 & 0.465 & 0.092 & 4.968 & 0.000 \\
$\mathrm{H}_{3}: \mathrm{OC} \rightarrow \mathrm{JP}$ & 0.451 & 0.446 & 0.090 & 5.037 & 0.000 \\
& \multicolumn{5}{c}{ Indirect Effect } \\
$\mathrm{H} 4: \mathrm{OCU} \rightarrow \mathrm{OC} \rightarrow \mathrm{JP}$ & 0.206 & 0.206 & 0.057 & 3.627 & 0.000 \\
\hline
\end{tabular}

**OC: Organizational Commitment, JP: Job performance: OCU, Organizational Culture.

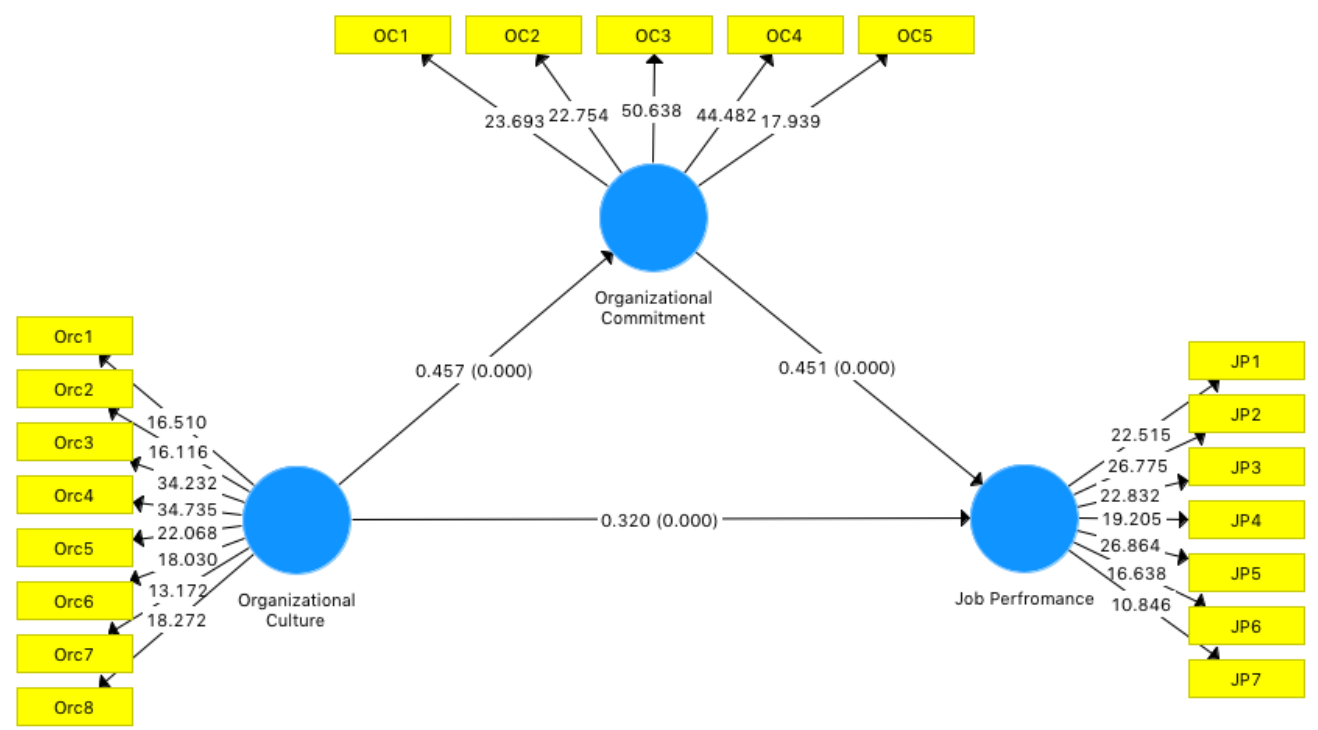

Figure 1. Structural model

\section{Discussion}

The purpose of this study has been achieved after the data analysis and the results discussed above. The first hypothesis examined the direct impact of OCU on JP. The result indicates that OCU significantly affects JP, which aligns with previous results (Carlos Pinho et al., 2014; Gani et al., 2018; Maamari \& Saheb, 2018; Raharjo et al., 2018). When it comes to boosting job performance, organizational culture is crucial. However, Organizational culture should be mandatory for all members and workers since this will foster uniformity among the organization's members. It will also improve staff 
productivity, commitment, and overall performance, emphasizing organizational culture's importance in fostering employee consistency. Thus, it may enhance group efficiency, commitment, and overall performance. Organizational culture is a set of fundamental ideas contributing to the organization's strength and stability due to cultural transformation. The advantages of good organizational culture in the workplace include improved mutual collaboration, unity, integrity, kinship, improved communication, and increased performance. Therefore, paying more attention to organizational culture is one way to increase job performance in the workplace. However, culture refers to an organization's values and qualities that differentiate itself from its rivals. Therefore, job performance is positively influenced by organizational culture. In addition, employee behavior is influenced by organizational culture, which motivates them to seek positive outcomes.

The second hypothesis has been confirmed and reported that organizational culture significantly impacts OC; this result is supported by several previous results (Gani et al., 2018; Raharjo et al., 2018; Sukasih \& Suardhika, 2019). This indicates that organizational culture and commitment may offer businesses a competitive advantage. An OCU that generates a high degree of comfort and trust will boost work behavior by increasing individual cohesiveness and corporate personnel commitment to achieve their best for the corporation.

Managers must understand the type of culture in their organization and then examine the strengths and weaknesses of such cultures in their workplace. Managers may need to design and establish organizational cultures more suitable to staff, and the organizational context since organizational culture appears to influence employee commitment. Managers must also define the core principles compatible with the company's culture. Later they may identify the type of individual or workers needed to fit the organization's culture and perform the given managing tasks. Managers should encourage their personnel to commit to improving the organization's success.

The third hypothesis measured the impact of OC on JP, and the result showed OC significantly impacts the JP; this result is in line with previous results (Gani et al., 2018; Raharjo et al., 2018; Sukasih \& Suardhika, 2019). Employees with a strong organizational commitment and more innovative and stable will drive the company to greater profitability. Individuals with a high organizational commitment are vital in achieving organizational goals; those with a low commitment are more concerned with fulfilling individual interests than the organization. This result also illustrates individuals' commitment to making businesses successful, and respondents' strong 
organizational commitment demonstrates how inventiveness and consistency help a company be lucrative and wealthy. Organizational commitment increases the efficiency of resources invested in enhancing job performance and reducing turnover and resistance to change in the workplace. The commitment may be built by developing a passion for people's work inside the workplace. Organizational commitment promotes job performance, which improves overall performance among employees. However, in particular, employees in the telecommunications sector have close interaction with consumers. As a result, their performance is often more apparent than employees in other businesses. These work outcomes' visibility may help enhance the link between OC and employee JP. As a result, organizational commitment may be even more critical in improving job performance. Employees with a stronger belief in, loyalty to, and intention to stay with a business may perform better in the workplace.

The last proposed hypothesis examined the mediating role of $\mathrm{OC}$ between OCU and JP, and the result showed the OC successfully mediated the impact of OCU on JP; several previous studies confirmed the mediating role of OC (Chiu et al., 2019; Chong \& Law, 2016; Hendri, 2019; Oyewobi et al., 2019; Raharjo et al., 2018). This study reported that OCU impacts JP through the mediating role of OC. Similar results reported that OC significantly mediated the relations between two variables or more (Oyewobi et al., 2019; Raharjo et al., 2018; Sihombing et al., 2018). Therefore, companies should enhance the OC in the workplace to increase organizational culture's impact on JP.

\section{Conclusion}

In conclusion, the current study's findings indicated that organizational commitment and culture significantly impact JP, and OC is significantly impacted by organizational culture. Finally, OC mediated the impact of OCU on JP.

Employee commitment, culture, and performance are essential to work and companies in developing countries because of the changing economic circumstances. As a result, this study has demonstrated the importance of these three variables in an organizational context, especially in developing countries. The results also point to a contingent link that must be considered when establishing effective management development programs for the company. Enhancing commitment, culture, and direction might help managers manage their individual goals and reach high performance. The current research may guide corporate owners and organizational leaders in developing commitment and direction by fostering a positive organizational 
culture and improving the organization. However, in today's competitive environment, management development programs should emphasize longterm commitment among personnel to enhance the organization's success.

\section{Declaration of conflicting interests}

The author(s) declared no potential conflicts of interest with respect to the research, authorship, and/or publication of this article.

\section{References}

Ahmad, A. R., Alhammad, A. H. Y., \& Jameel, A. S. (2021). National Culture, Leadership Styles and Job Satisfaction: An Empirical Study in the United Arab Emirates. Journal of Asian Finance, Economics, and Business, 8(6), 1111-1120. https://doi.org/10.13106/jafeb.2021.vol8.no6.1111

Ahmad, A. R., Keerio, N., Jameel, A. S., \& Karem, M. A. (2020). The Relationship between National Culture and Succession Planning in Malaysian Public Universities. Journal of Education and E-Learning Research, 7(3), 242-249.

Al-Musadieq, M., Nurjannah, N., Raharjo, K., Solimun, S., \& Achmad Rinaldo Fernandes, A. (2018). The mediating effect of work motivation on the influence of job design and organizational culture against HR performance. Journal of Management Development, 37(6), 452-469. https://doi.org/10.1108/JMD-07-2017-0239

Al-Sada, M., Al-Esmael, B., \& Faisal, M. N. (2017). Influence of organizational culture and leadership style on employee satisfaction, commitment and motivation in the educational sector in Qatar. EuroMed Journal of Business, 12(2), 163-188. https://doi.org/10.1108/EMJB-02-2016-0003

Alferaih, A. (2017). Developing a conceptual model to measure talent's turnover intention in tourism organisations of Saudi Arabia. International Journal of Organizational Analysis, 25(1), 2-23. https://doi.org/10.1108/JJOA-10-2014-0803

Allen, N. J., \& Meyer, J. P. (1996). Affective, continuance, and normative commitment to the organization: An examination of construct validity. Journal of Vocational Behavior, 49(3), 252-276. https://doi.org/10.1006/jvbe.1996.0043

Aranki, D. H., Suifan, T. S., \& Sweis, R. J. (2019). The relationship between organizational culture and organizational commitment. Modern Applied Science, 13(4), 137-154. https://doi.org/10.5539/mas.v13n4p137

Beyer, S. (1990). Gender differences in the accuracy of self-evaluations of performance. Journal of Personality and Social Psychology, 59(5), 960.

Carlos Pinho, J., Paula Rodrigues, A., \& Dibb, S. (2014). The role of corporate culture, market orientation and organisational commitment in organisational performance. Journal of Management Development, 33(4), 374-398. https://doi.org/10.1108/JMD03-2013-0036

Chapman, D. S., Uggerslev, K. L., Carroll, S. A., Piasentin, K. A., \& Jones, D. A. (2005). Applicant Attraction to Organizations and Job Choice: A Meta-Analytic Review of the Correlates of Recruiting Outcomes. Journal of Applied Psychology, 90(5), 928-944. https://doi.org/10.1037/0021-9010.90.5.928

Chatman, J. A., Polzer, J. T., Barsade, S. G., and Neale, M. A. (1998). Being different yet feeling similar: The influence of demographic composition and organizational culture 
on work processes and outcomes. Administrative Science Quarterly, 749-780. https://doi.org/10.2307/2393615

Chiu, W., Won, D., \& Bae, J. (2019). Internal marketing, organizational commitment, and job performance in sport and leisure services. Sport, Business and Management: An International Journal, 10(2), 105-123. https://doi.org/10.1108/SBM-09-2018-0066

Chong, V. K., \& Law, M. B. C. (2016). The effect of a budget-based incentive compensation scheme on job performance. Journal of Accounting \& Organizational Change, 12(4), 590-613. https://doi.org/10.1108/JAOC-02-2015-0024

Cohen, J. (1988). Statistical power analysis for the behavioral sciences. Academic Press.

Denison, M., \& Misra, A. K. (1995). Toward a Theory of Organizational Culture and $\begin{array}{lll}\text { Effectiveness. } & \text { Organization } & \text { Science, }\end{array}$ https://doi.org/10.1287/orsc.6.2.204

Fornell, C., \& Larcker, D. F. (1981). Evaluating Structural Equation Models with Unobservable Variables and Measurement Error. Journal of Marketing Research, 18(1), 39-50. https://doi.org/10.2307/3151312

Gani, M. U., Muh, N. H., \& Arifin, Z. (2018). The mediating role of organizational commitment of job performance: The Impacts of Leadership, job competency, and organizational culture. Archives of Business Research, 6(11). https://doi.org/10.14738/abr.611.5609

Gibson, J., Ivancevich, J., \& Konopaske, R. (2011). Organizations: Behavior, structure, processes. McGraw-Hill Higher Education.

Hair Jr, J. F., Hult, G. T. M., Ringle, C. M., \& Sarstedt, M. (2017). A primer on partial least squares structural equation modeling (PLS-SEM). Sage publications.

Hamdi, S. S., Jameel, A. S., Massoudi, A. H., \& Ahmad, A. R. (2021). Leadership Style and Organizational Citizenship Behavior in Secondary Schools. 3rd International Conference on Administrative \& Financial Sciences (ICAFS 2021). https://doi.org/10.24086/afs2020/paper.231

Hendri, M. I. (2019). The mediation effect of job satisfaction and organizational commitment on the organizational learning effect of the employee performance. International Journal of Productivity and Performance Management, 68(7), 1208-1234. https://doi.org/10.1108/IJPPM-05-2018-0174

Hofstede, G. (1984). Culture's consequences: International differences in work-related values (Vol. 5). Sage publications.

Hofstede, G. (2011). Dimensionalizing cultures: The Hofstede model in context. Online Readings in Psychology and Culture, 2(1), 919-2307. https://doi.org/10.9707/23070919.1014

Hofstede, G., Neuijen, B., Ohayv, D. D., \& Sanders, G. (1990). Measuring Organizational Cultures: A Qualitative and Quantitative Study Across Twenty Cases. Administrative Science Quarterly, 35(2), 286. https://doi.org/10.2307/2393392

Huey Yiing, L., \& Zaman Bin Ahmad, K. (2009). The moderating effects of organizational culture on the relationships between leadership behaviour and organizational commitment and between organizational commitment and job satisfaction and performance. Leadership \& Organization Development Journal, 30(1), 53-86. https://doi.org/10.1108/01437730910927106

Isaac Mwita, J. (2000). Performance management model. International Journal of Public Sector Management, 13(1), 19-37. https://doi.org/10.1108/09513550010334461

Jameel, A.S., \& Ahmad, A. R. (2020). The mediating role of job satisfaction between leadership style and performance of academic staff. International Journal of Psychosocial Rehabilitation, 24(4), 2399-2414. 
https://doi.org/10.37200/IJPR/V24I4/PR201349

Jameel, A. S., \& Ahmad, A. R. (2019a). The Effect of Transformational Leadership on Job Satisfaction among Academic Staff. In The 34th International Business Information Management Association (IBIMA) Conference: 13-14 November 2019. Madrid, Spain. Jameel, A. S., \& Ahmad, A. R. (2019b). Leadership and performance of academic staff in developing countries. Proceedings of the 33rd International Business Information Management Association Conference, IBIMA 2019: Education Excellence and Innovation Management through Vision 2020. 6101-6106. https://doi.org/10.2139/ssrn.3432988

Jameel, A. S., Ahmad, A. R., \& Mousa, T. S. (2020). Organizational justice and job performance of academic staff at public universities in Iraq. SKYLINE BUSINESS JOURNAL, 16(1). https://doi.org/10.37383/SBJ160102

Jameel, A. S, Hamdi, S. S., Karem, M. A., \& Ahmad, A. R. (2020). Organizational Justice and Job satisfaction among nurses. UKH Journal of Social Sciences, 4(2). https://doi.org/10.25079/ukhjss.v4n2y2020.pp61-69

Jameel, A. S, Mahmood, Y. N., \& Jwmaa, S. J. (2020). Organisational Justice and Organisational Commitment among Secondary School Teachers. Cihan UniversityErbil Journal of Humanities and Social Sciences, 4(1), 1-6.

Judge, T. A., \& Watanabe, S. (1993). Another look at the job satisfaction-life satisfaction relationship. Journal of Applied Psychology, 78(6), 939.

Karem, M. A., Jameel, A. S., \& Ahmad, A. R. (2019). The Impact of Organizational Justice Dimensions on Organizational Commitment among Bank Employees. International Journal of Psychosocial Rehabilitation, 23(02), 502-513.

Karem, M. A., Mahmood, Y. N., Jameel, A. S., \& Ahmad, A. R. (2019). The Effect of Job Satisfaction and Organizational Commitment on Nurses' Performance. Humanities and Social Sciences Reviews, 7(6), 332-339. https://doi.org/10.18510/hssr.2019.7658

Kline, R. B. (2016). Principles and practices of structural equation modelling. In Methodology in the social sciences (4th ed.). Guilford.

Maamari, B. E., \& Saheb, A. (2018). How organizational culture and leadership style affect employees' performance of genders. International Journal of Organizational Analysis, 26(4), 630-651. https://doi.org/10.1108/IJOA-04-2017-1151

Massoudi, A. H., Jameel, A. S., \& Ahmad, A. R. (2020). Stimulating organizational citizenship behavior by applying organizational commitment and satisfaction. International Journal of Social Sciences and Economic Review, 2(2), 20-27.

McColl-Kennedy, J. R., \& Anderson, R. D. (2002). Impact of leadership style and emotions on subordinate performance. The Leadership Quarterly, 13(5), 545-559. https://doi.org/10.1016/S1048-9843(02)00143-1

Meyer, \& Allen, N. J. (1997). Commitment in the workplace: Theory, research, and application. Sage.

Meyer, J. P., \& Allen, N. J. (1991). A three-component conceptualization of organizational commitment. Human Resource Management Review, 1(1), 61-89. https://doi.org/10.1016/1053-4822(91)90011-Z

Meyer, J. P., Paunonen, S. V, Gellatly, I. R., Goffin, R. D., \& Jackson, D. N. (1989). Organizational commitment and job performance: It's the nature of the commitment that counts. Journal of Applied Psychology, 74(1), 152.

Mowday, R. T., Porter, L. W., \& Steers, R. M. (1982). Employee-organization linkages: The psychology of commitment, absenteeism, and turnover. Academic Press.

Oyewobi, L. O., Oke, A. E., Adeneye, T. D., \& Jimoh, R. A. (2019). Influence of organizational commitment on work-life balance and organizational performance of 
female construction professionals. Engineering, Construction and Architectural Management, 26(10), 2243-2263. https://doi.org/10.1108/ECAM-07-2018-0277

Porter, L. W., Steers, R. M., Mowday, R. T., \& Boulian, P. V. (1974). Organizational commitment, job satisfaction, and turnover among psychiatric technicians. Journal of Applied Psychology, 59(5), 603.

Pujiono, B., Setiawan, M., Sumiati, \& Wijayanti, R. (2020). The effect of transglobal leadership and organizational culture on job performance - Inter-employee trust as Moderating Variable. International Journal of Public Leadership, 16(3), 319-335. https://doi.org/10.1108/IJPL-11-2019-0071

Raharjo, K., Nurjannah, N., Solimun, S., \& Achmad Rinaldo Fernandes, A. (2018). The influence of organizational culture and job design on job commitment and human resource performance. Journal of Organizational Change Management, 31(7), 13461367. https://doi.org/10.1108/JOCM-07-2017-0286

Randall, D. M. (1990). The consequences of organizational commitment: Methodological investigation. Journal of Organizational Behavior, 11(5), 361-378.

Randeree, K., \& Ghaffar Chaudhry, A. (2012). Leadership - style, satisfaction and commitment. Engineering, Construction and Architectural Management, 19(1), 6185. https://doi.org/10.1108/09699981211192571

Robbins, S. P., \& Judge, T. A. (2003). Organizational Behavior Prentice Hall. New Jersey, USA.

Schein, E. H. (1991). What is culture? Newbury Park, CA: Sage, 243-253.

Sihombing, S., Astuti, E. S., Al Musadieq, M., Hamied, D., \& Rahardjo, K. (2018). The effect of servant leadership on rewards, organizational culture and its implication for employee's performance. International Journal of Law and Management, 60(2), 505516. https://doi.org/10.1108/IJLMA-12-2016-0174

Suharnomo, S., \& Hashim, F. (2019). Differences in organization citizenship behavior between "Serumpun" countries (Indonesia - Malaysia). Journal of Asia Business Studies, 13(3), 349-361. https://doi.org/10.1108/JABS-12-2016-0178

Sukasih, N. N., \& Suardhika, I. N. (2019). Organizational Culture, Organizational Justice, Employee Performance, Organizational Commitments in Bali Province Income Area. International Journal of Sustainability, Education, And Global Creative Economic, 2(3), 301-309.

Thabit, T., \& Raewf, M. B. (2017). Applications of Fuzzy Logic in Finance Studies. LAP LAMBERT Academic Publishing.

Trice, H. M., \& Beyer, J. M. (1993). The cultures of work organizations. Prentice-Hall, Inc. Wallach, E. J. (1983). Individuals and organizations: The cultural match. Training \& Development Journal.

Xiu, L., Dauner, K. N., \& McIntosh, C. R. (2019). The impact of organizational support for employees' health on organizational commitment, intent to remain and job performance. Evidence-Based HRM: A Global Forum for Empirical Scholarship, 7(3), 281-299. https://doi.org/10.1108/EBHRM-10-2018-0062 